\title{
An integrated study of the biodiversity within the Pseudechiniscus suillus-facettalis group (Heterotardigrada: Echiniscidae)
}

\author{
MICHELE CESARI ${ }^{1}$, MARTINA MONTANARI ${ }^{1}$, REINHARDT M. KRISTENSEN ${ }^{2}$, \\ ROBERTO BERTOLANI ${ }^{3,4}$, ROBERTO GUIDETTI ${ }^{1, *}$ and LORENA REBECCHI ${ }^{1}$ \\ ${ }^{1}$ Department of Life Sciences, University of Modena and Reggio Emilia, Italy \\ ${ }^{2}$ The Natural History Museum of Denmark, University of Copenhagen, Denmark \\ ${ }^{3}$ Department of Education and Humanities, University of Modena and Reggio Emilia, Italy \\ ${ }^{4}$ Civic Museum of Natural History, Verona, Italy
}

Received 31 October 2018; revised 23 April 2019; accepted for publication 9 May 2019

\begin{abstract}
Pseudechiniscus is the second most species-rich genus in Heterotardigrada and in the family Echiniscidae. However, previous studies have pointed out polyphyly and heterogeneity in this taxon. The recent erection of the genus Acanthechiniscus was another step in making Pseudechiniscus monophyletic, but species identification is still problematic. The present investigation aims at clarifying biodiversity and taxonomy of Pseudechiniscus taxa, with a special focus on species pertaining to the so-called 'suillus-facettalis group', by using an integrated approach of morphological and molecular investigations. The analysis of sequences from specimens sampled in Europe and Asia confirms the monophyly of the genus Pseudechiniscus. Inside the genus, two main evolutionary lineages are recognizable: the $P$. novaezeelandiae lineage and the $P$. suillus-facettalis group lineage. Inside the $P$. suillusfacettalis group, COI molecular data points out a very high variability between sampled localities, but in some cases also among specimens sampled in the same locality (up to $33.3 \%$ p-distance). The integrated approach to the study of Pseudechiniscus allows confirmation of its monophyly and highlights the relationships in the taxon, pointing to its global distribution.
\end{abstract}

KEYWORDS: $18 \mathrm{~S}$ - 28S - cytochrome $c$ oxidase I - Pseudechiniscus facettalis - scanning electron microscope Pseudechiniscus suillus - Tardigrada - water bears.

\section{INTRODUCTION}

The phylum Tardigrada consists of more than 1200 described species (Guidetti \& Bertolani, 2005; Degma \& Guidetti, 2007; Degma et al., 2018), subdivided into three classes: Eutardigrada, Mesotardigrada and Heterotardigrada (Ramazzotti \& Maucci, 1983). The latter class is mainly made up of semi-terrestrial or marine species, and it is subdivided into two orders: Arthrotardigrada and Echiniscoidea (Marcus, 1929). Inside Echiniscoidea, the second most species-rich genus is Pseudechiniscus Thulin, 1911, surpassed only by the genus Echiniscus C. A. S. Schultze, 1840 (Degma et al., 2018; Gasiorek et al., 2018c). However,

*Corresponding author. E-mail: roberto.guidetti@unimore.it
Pseudechiniscus has always been controversial. For example, Maucci (1973-74) and Dastych (1984) suggested a complete revision of the genus. It was finally emended by Kristensen (1987), but two main groups inside the genus were still distinguished: the $P$. suillus / conifer group, characterized by the absence of trunk cirri; and the P. victor group, identifiable with the presence of trunk cirri. Moreover, the advent of molecular investigations quickly pointed to polyphyly in Pseudechiniscus (Jørgensen et al., 2011; Guil \& Giribet, 2012; Guil et al., 2013). A recent integrative analysis (Vecchi et al., 2016) has led to the erection of the genus Acanthechiniscus, more or less corresponding to the old P. victor group, another step in making Pseudechiniscus monophyletic, with the genus now comprising 40 described species (Degma et al., 2018). 
The high number of described species notwithstanding, species identification is still difficult in Pseudechiniscus (Kathman \& Dastych, 1990; Fontoura \& Morais, 2011). Some of the species are difficult to distinguish from one another, which is due to different issues, such as older, imprecise or incomplete diagnoses (for actual standards) with omissions of important characters, probably linked to the use of poor equipment and, in some cases, the type material being absent or lost (Fontoura \& Morais, 2011). Moreover, some characters are subject to different interpretations, e.g. faceted cephalic and terminal plates, fine or coarse dorsal granulation and small cones on lateral positions. In addition, there is still some confusion between $P$. suillus (Ehrenberg, 1853), the type species, and $P$. facettalis Petersen, 1951 , especially concerning the subdivision of the pseudosegmental plate and the faceting on the terminal plate, a highly variable character (Kathman \& Dastych, 1990; Fontoura \& Morais, 2011). Interestingly, even in the original description, Petersen (1951) described $P$. facettalis as a form of $P$. suillus, stating 'the differences are not so great that it can be apprehended as an independent species'.

The present investigation aims at studying the diversity and taxonomy of Pseudechiniscus taxa, using an integrated approach of morphological (light and scanning electron microscopy) and molecular (18S, $28 \mathrm{~S}$ and COI genes) investigations in order to elucidate relationships in the genus Pseudechiniscus, with a special focus on species pertaining to the P. suillusfacettalis group.

\section{MATERIAL AND METHODS}

Mosses were sampled in five different localities in Eurasia (Table 1). After soaking a fragment of the moss for half an hour, tardigrades were extracted from samples by repeatedly washing and squeezing the fragment through consecutive $500-\mu \mathrm{m}$ and $38-\mu \mathrm{m}$ sieves. Tardigrades pertaining to the genus Pseudechiniscus were individually isolated using a needle and a glass pipette under a stereomicroscope. The remaining fractions of the samples are stored at $-80{ }^{\circ} \mathrm{C}$ in the Biobank of the Evozoo Lab at the Department of Life Sciences (University of Modena and Reggio Emilia, Italy - UNIMORE).

Tardigrades (53 specimens) were mounted in FaureBerlese mounting medium for observations under light microscopy (LM), while the other 28 animals were prepared for scanning electron microscopy (SEM), following the protocol described in Bertolani et al. (2011b). Observations with LM were carried out with both phase contrast $(\mathrm{PhC})$ and differential interference contrast (DIC) up to the maximum magnification (objective $100 \times$ with oil immersion) with a Leica DM RB microscope, equipped with a digital camera Nikon DS-Fi 1, at UNIMORE. Observations with SEM were carried out with a Nova Nano SEM 450 (FEI Company - Oxford Instruments), available at the 'Centro Interdipartimentale Grandi Strumenti' at UNIMORE. All slides are deposited in Bertolani's collection at the Department of Life Sciences, UNIMORE. Unfortunately, for all studied populations, morphometric data according to Fontoura \& Morais (2011) were impossible to collect, because most specimens on slides were in an unsuitable position for the measurement of the scapular plate. The latter was almost never in only one focal plane, preventing its measurement. Moreover, in the few slides in which the scapular plate was completely visible in only one focal plane, the specimens were so flattened that the edge of all the other dorsal plates were not identifiable and, therefore, impossible to measure.

A total of 27 specimens were utilized for molecular analyses (Table 1; Supporting Information, Table S1). Before total DNA isolation, single Pseudechiniscus specimens were temporally mounted in water on a slide, and observed and identified at LM up to $100 \times$

Table 1. Geographical information of sampled localities and number of Pseudechiniscus specimens used for molecular analyses

\begin{tabular}{|c|c|c|c|c|c|c|c|}
\hline Sample & Locality & $\begin{array}{l}\text { Sampling } \\
\text { Year }\end{array}$ & Latitude; Longitude & $\begin{array}{l}\text { Elevation } \\
\text { (m a.s.l.) }\end{array}$ & $18 \mathrm{~S}$ & $28 \mathrm{~S}$ & $\mathrm{COI}$ \\
\hline C2592 & Orkhon Valley - Mongolia & 2004 & $046^{\circ} 47.311^{\prime} \mathrm{N} ; 101^{\circ} 57.848^{\prime} \mathrm{E}$ & 1790 & 6 & 6 & 6 \\
\hline C2595 & $\begin{array}{l}\text { Khangai Nuruu National Park - } \\
\text { Mongolia }\end{array}$ & 2004 & $046^{\circ} 38.288^{\prime} \mathrm{N} ; 101^{\circ} 17.089^{\prime} \mathrm{E}$ & 2792 & 4 & 4 & 2 \\
\hline C3019 & Velkyvodaped - Slovakia & 2009 & $048^{\circ} 56.311^{\prime} \mathrm{N} ; 020^{\circ} 21.260^{\prime} \mathrm{E}$ & 624 & 4 & 4 & 4 \\
\hline $\begin{array}{l}\text { C3039, } \\
\text { C3040 }\end{array}$ & $\begin{array}{l}\text { Carvalhal da Moita do Conqueiro - } \\
\text { Portugal }\end{array}$ & 2007,2006 & $040^{\circ} 23.833^{\prime} \mathrm{N} ; 007^{\circ} 38.067^{\prime} \mathrm{W}$ & 1134 & 5 & 5 & 3 \\
\hline \multirow[t]{2}{*}{ C3842 } & Avise - Italy & 2014 & $045^{\circ} 42.883^{\prime} \mathrm{N} ; 007^{\circ} 07.350^{\prime} \mathrm{E}$ & 1145 & 6 & 6 & 2 \\
\hline & & & Total number of specimens & & 25 & 25 & 17 \\
\hline
\end{tabular}


magnification, following the protocol described in Cesari et al. (2011). Voucher images of taxonomically relevant structures (i.e. cuticle, papillae, spines, buccalpharyngeal apparatus and claws) were recorded for each specimen and are available upon request. Genomic DNA was extracted from single tardigrades using the MasterPure Complete DNA and RNA Purification kit (Epicentre - Illumina, Madison, WI, USA), following the manufacturer's protocol. A region of the nuclear ribosomal small subunit gene (18S) was amplified with the primers and protocols described in Vicente et al. (2013), whereas a region of the nuclear ribosomal large subunit gene (28S) was amplified with the primers and protocols as described in Guidetti et al. (2014). A portion of the mtDNA cytochrome $c$ oxidase I gene (COI) was carried out using primers LCO (5'GGT CAA CAA ATC ATA AAG ATA TTG G-3') and HCOout (5'-CCA GGT AAA ATT AAA ATA TAA ACT TC-3'), with the following protocol: initial denaturation at $94{ }^{\circ} \mathrm{C}$ for $5 \mathrm{~min}$, followed by five cycles of $94{ }^{\circ} \mathrm{C}$ for $1 \mathrm{~min}, 45^{\circ} \mathrm{C}$ for $1 \mathrm{~min} 30 \mathrm{~s}$ and $72{ }^{\circ} \mathrm{C}$ for $1 \mathrm{~min}$ $30 \mathrm{~s}$, succeeded by 35 cycles of $94{ }^{\circ} \mathrm{C}$ for $30 \mathrm{~s}, 50{ }^{\circ} \mathrm{C}$ for $30 \mathrm{~s}$ and $72^{\circ} \mathrm{C}$ for $1 \mathrm{~min}$, with a final extension step of $72{ }^{\circ} \mathrm{C}$ for $6 \mathrm{~min}$. The amplified products were gel purified using the Wizard Gel and PCR cleaning (Promega) kit, while sequencing reactions were performed using the ABIPRISM BigDye Terminator v.1.1 Sequencing Kit (Applied Biosystems, Foster City, CA, USA) on purified amplicons. Each sequencing reaction contained $0.2 \mu \mathrm{M}$ of a single PCR primer to initiate the sequencing reaction, $2 \mu \mathrm{L}$ of BigDye, $70 \mathrm{ng}$ of purified products, $4 \mu \mathrm{L}$ of $5 x$ BigDye Terminator v.1.1 Sequencing Buffer (Applied Biosystems, Foster City, CA, USA) and twice distilled $\mathrm{H}_{2} \mathrm{O}$ for a final volume of $20 \mu \mathrm{L}$. Cycling conditions for sequencing reactions consisted of 25 cycles of $96{ }^{\circ} \mathrm{C}$ for $10 \mathrm{~s}, 50^{\circ} \mathrm{C}$ for $5 \mathrm{~s}$ and $60{ }^{\circ} \mathrm{C}$ for $4 \mathrm{~min}$. Both strands were sequenced using an ABI Prism 3100 (Applied Biosystems, Foster City, CA, USA). Nucleotide sequences of the newly analysed specimens were submitted to GenBank (accession numbers: MK804894-MK804955; see Supporting Information, Table S1).

For $18 \mathrm{~S}$ and $28 \mathrm{~S}$ gene analysis, nucleotide sequences were aligned with the MAFFT algorithm (Katoh et al., 2002), as implemented in the MAFFT online service (Katoh et al., 2017) and checked by visual inspection. Sequences pertaining to a Florarctus sp. (Heterotardigrada, Arthrotardigrada; GenBank acc. nos.: GQ849017 for the 18S gene, GQ849034 for the 28S gene; Jørgensen et al., 2010) specimen were used as outgroup. Other Echiniscoidea sequences from GenBank were also included in the analysis for appropriate comparisons (Supporting Information, Table S2). A Bayesian inference dendrogram was computed with the program MrBayes v.3.2.6 (Huelsenbeck \& Ronquist, 2001; Ronquist \&
Huelsenbeck, 2003) as implemented in CIPRES v.2.0 (Miller et al., 2010). Best-fitting model evaluations were performed taking into account the Corrected Akaike Information Criterion (jModelTest v.2.1.10; Guindon \& Gascuel, 2003; Darriba et al., 2012), which identified the TPM1+I+G model for the $18 \mathrm{~S}$ gene and the GTR+G model for the $28 \mathrm{~S}$ gene as the most suitable. The TPM+I+G model was replaced by the GTR $+\mathrm{I}+\mathrm{G}$ model in the MrBayes' analysis. Two independent runs, each of four Metropolis-coupled Markov chains Monte Carlo method, were launched for $30 \times 10^{6}$ generations and trees were sampled every 1000 generations. Convergence of runs was assessed by tracking average standard deviation of split frequencies between runs and by plotting the log likelihood of sampled trees in TRACER v.1.5 (Rambaut \& Drummond, 2007) and the first $3 \times 10^{6}$ sampled generations were discarded as burn-in. A maximum likelihood (ML) analysis was performed with the program RAxML v.7.2.4 (Stamatakis, 2006), as implemented in CIPRES, using the models described above. Bootstrap resampling with 1000 replicates was undertaken via the rapid bootstrap procedure of Stamatakis et al. (2008) to assign support to branches in the ML tree.

For COI gene analysis, chromatograms obtained were checked for the presence of ambiguous bases. Sequences were translated into amino acids by using the invertebrate mitochondrial code implemented in MEGA7 (Kumar et al., 2016) in order to check for the presence of stop codons and, therefore, of pseudogenes. Nucleotide sequences were aligned with the MAFFT algorithm, as described above, and checked by visual inspection. For appropriate molecular comparisons, COI sequences from GenBank pertaining to other Echiniscidae specimens (Supporting Information, Table S2) were considered in the analysis. Pairwise nucleotide sequence divergences between scored haplotypes were computed using p-distance with MEGA7. The relationships among COI haplotypes were estimated using a parsimony network by applying the method described by Templeton et al. (1992), as implemented in TCS v.1.21 (Clement et al., 2000) and visualized using tcsBU (Santos et al., 2015). A 95\% connection limit was used as a useful general tool in species assignments and discovery (Hart \& Sunday, 2007). Putative species were also inferred by using the Poisson Tree Process (PTP; Zhang et al., 2013) and the Automatic Barcode Gap Discovery method (ABGD; Puillandre et al., 2012). PTP is a coalescentbased species delimitation method that use nonultrameric gene trees as input, and utilizes heuristic algorithms to identify speciation events relative to numbers of substitutions. The PTP method produces robust diversity estimates, in some cases more robust than those estimated under the generalized mixed Yule coalescent model (Tang et al., 2014). The starting 
gene tree was a ML tree computed using RAxML under the GTR+G model with the same procedure as described above for the $18 \mathrm{~S}$ gene. In the distancebased ABGD method, the sequences are sorted into hypothetical species based on the barcode gap (i.e. whenever the divergence among organisms belonging to the same species is smaller than divergence among organisms from different species). The method first detects the barcode gap as the first significant gap beyond a model-based one-sided confidence limit for intraspecific divergence, and then uses it to partition the data. ABGD settings for the COI dataset were: prior minimum divergence of intraspecific diversity $\left(\mathrm{P}_{\min }\right)=0.001$; prior maximum divergence of intraspecific diversity $\left(\mathrm{P}_{\max }\right)=0.1 ;$ Steps $=10$ and gap width $=1.5$. The analysis was performed on the ABGD website (http://wwwabi.snv.jussieu.fr/public/abgd/ abgdweb.html).

\section{RESULTS}

The morphological analyses with LM and SEM of all investigated Pseudechiniscus specimens evidence the presence of pedal (leg) plates, the absence of the spine on the first leg pair and a dome-like cephalic papilla (Figs 1A, B, 2A, B, 3A, B, 4A, B). The latter character points to their belonging to the 'suillus-facettalis' species group (Petersen, 1951). Although the cephalic and caudal plates' faceting should allow a clear attribution of the specimens to either the $P$. suillus (no plate faceting) or to the $P$. facettalis (plate faceting present; Ramazzotti \& Maucci, 1983; Gąsiorek \& Degma, 2018), this character is not clear and does not help in unambiguously identifying specimens (Figs 1C, D, 2C, D, 3C, D, 4C, D). All sampled localities feature male and female specimens. The female gonopore is made up of six cuticular folds that appear as a roselike structure (Fig. 1E, F), while the male gonopore is round (Fig. 3E, F). These data point to the bisexual condition of analysed specimens.

The specimens pertaining to the Slovak sample (C3019; Fig. 1) have a peculiar ventral sculpture with respect to all other analysed specimens. The sculpture is made up of the heads of the intracuticular pillars that appear as dotted areas forming a reticulate pattern (Fig. 1E, F). This peculiar reticulation is very similar to that of Pseudechiniscus xiai Wang et al., 2018 . The only differences found between these species are the division of median plate 2 in the Slovak sample (undivided in P. xiai) and the not uniform terminal plate in the Slovakian specimens, which presents notches, as depicted in fig. 10, p. 45 of Petersen (1951). In $P$. xiai, the terminal plate is without notches, nor faceted.
All other analysed specimens (Figs 2-4) present no evident differences in the cuticle ventral sculpture, which is made up of the heads of the intracuticular pillars forming a fine uniform granulation that becomes coarser between the legs and in correspondence of the gonopore (Figs 2E, F, 3E, F, 4E, F).

The phylogenetic inference based on $1652 \mathrm{bp}$ of the $18 \mathrm{~S}+28 \mathrm{~S}$ genes (Fig. 5) shows Echiniscoides branching of the base with respect to a group with all other Echiniscoidea taxa. Inside the latter cluster, the Parechiniscus genus is sister to five main lineages: the Hypechiniscus + Testechiniscus + Diploechiniscus + Echiniscus cluster, three different lineages representing the genera Mopsechiniscus, Oreella and Bryodelphax, respectively, and a large group containing four other genera. Inside this latter cluster, two main lineages can be observed: one groups Proechiniscus, Cornechiniscus and Acanthechiniscus, while the other clusters all Pseudechiniscus specimens. The Pseudechiniscus lineage is subdivided into two highly supported clusters: one groups a sequence from GenBank misidentified as Echiniscus sp. with Pseudechiniscus titianae Vecchi et al., 2016 (characterized by an elongated cephalic papilla, typical of the Pseudechiniscus novaezaelandiae group), while all sequences grouped inside the second cluster belong to specimens with a dome-like cephalic papilla, which characterizes the species pertaining to the P. suillus-facettalis group. This second cluster is divided into two main groups: (1) one sequence from a Mongolian specimen belonging to the first cluster, together with $P$. facettalis specimens from Greenland and (2) all other sequences obtained from newly analysed specimens belonging to a highly supported group comprising also Norwegian and Spanish sequences from GenBank, with the sequences from Slovakian specimens sister to all. No clear-cut division between P. suillus and P. facettalis is found; both species are comprised in the latter cluster.

The analyses of $675 \mathrm{bp}$ of the COI gene of the Pseudechiniscus specimens show a high variability. Ten new haplotypes are found among 15 specimens. The genetic p-distances between scored haplotypes (Supporting Information, Table S3) are in the range of $0.2-33.3 \%$. Inside each sampled location, p-distances are generally low (Portugal: 0.0-1.7\%; Slovakia: 0.0-0.2\%; Italy: $0 \%$ ), with the exception of both Mongolian samples, where a very high variability (up to $33.3 \%$ p-distance) is found among specimens. The PTP analysis (Fig. 6) shows nine putative species clusters: one each for Portuguese (together with Spanish $P$. facettalis specimens from GenBank), Italian, Slovakian and Greenlandic specimens. On the other hand, the Mongolian specimens are subdivided into five different putative species. This subdivision 

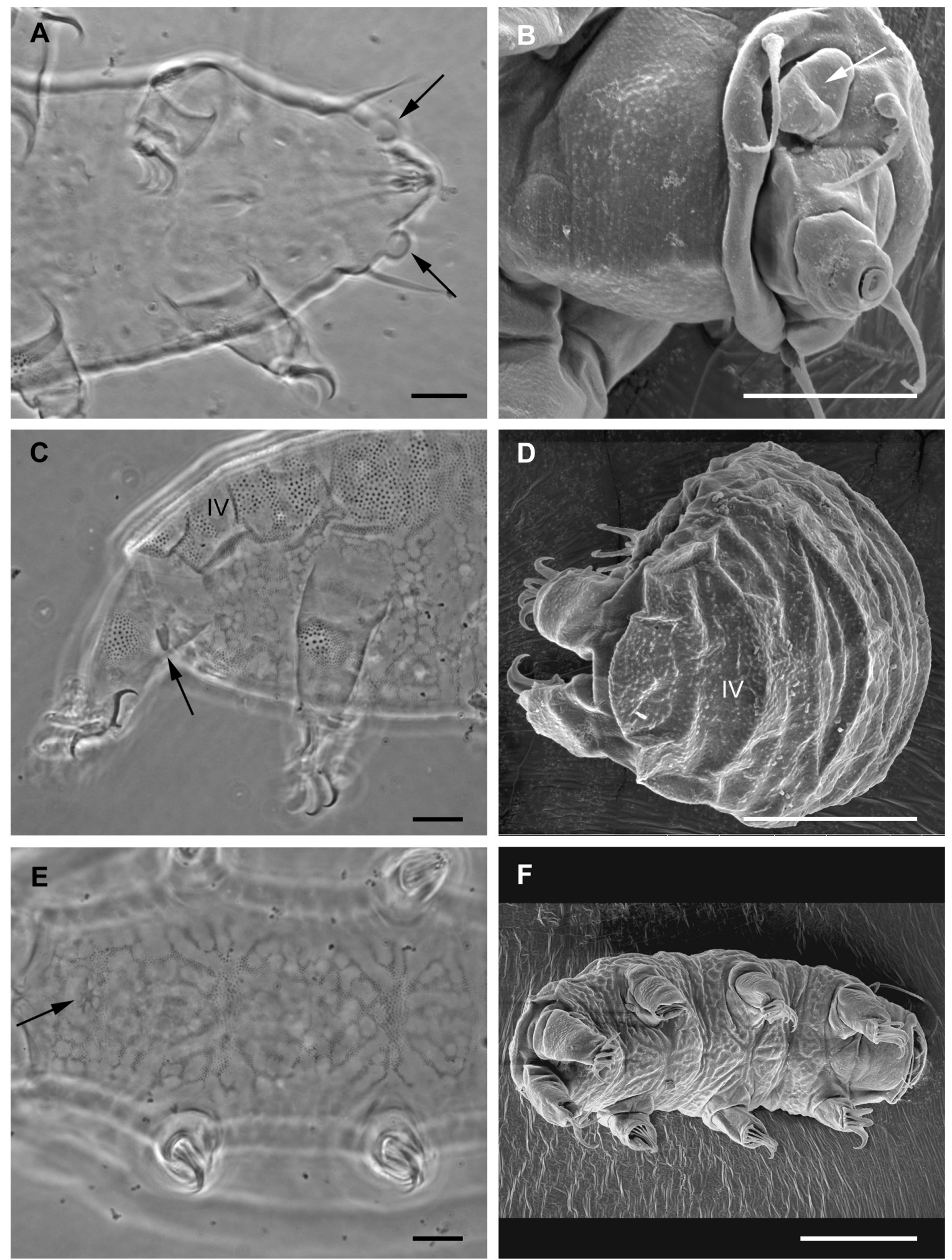

Figure 1. Pseudechiniscus specimens from Slovakia (C3019), light microscopy (LM, phase contrast) and scanning electron microscopy (SEM). A, cephalic papillae (arrows, LM). B, head with cephalic papilla (arrow, SEM). C, terminal (caudal) plate (IV) and papilla (arrow) on the fourth pair of legs (LM). D, terminal (caudal) plate (IV; SEM). E, ventral sculpture and female gonopore (arrow; LM). F, in toto animal with evident ventral sculpture (SEM). Pores in D are artefacts due to sample preparation. Scale bars: $10 \mu \mathrm{m}$ (A, B, C, E); $20 \mu \mathrm{m}(\mathrm{D}) ; 30 \mu \mathrm{m}(\mathrm{F})$. 

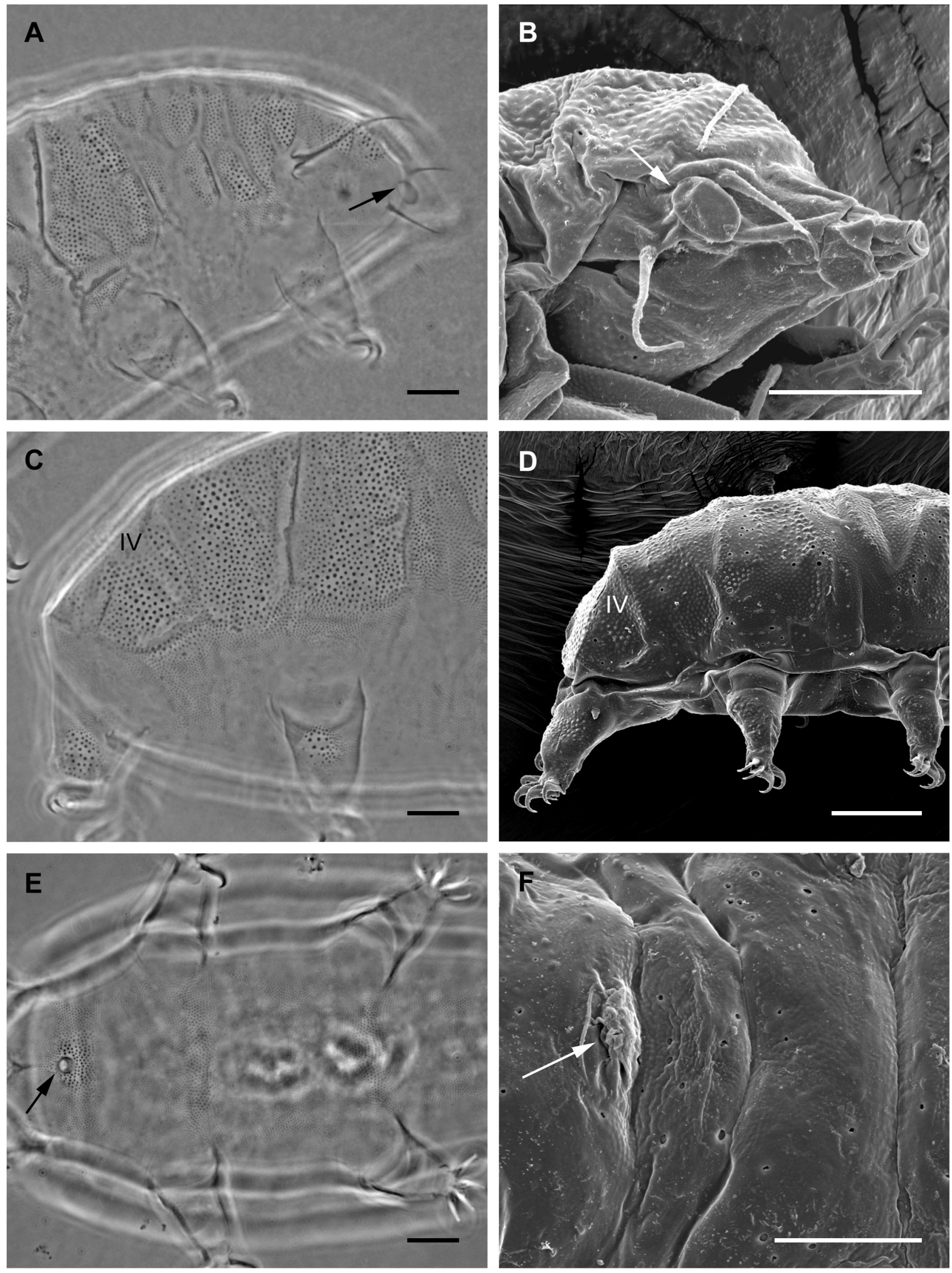

(C) 2019 The Linnean Society of London, Zoological Journal of the Linnean Society, 2020, 188, 717-732 
is confirmed by both the ABGD and the haplotype network analysis (Fig. 6).

\section{DISCUSSION}

The integrated approach to the study of Pseudechiniscus allows us to confirm and clarify its taxonomic position. Our new data confirm the subdivision between Acanthechiniscus and Pseudechiniscus identified by Vecchi et al. (2016) and also points out that all specimens sampled in European, Asian, Arctic and Antarctic regions belong to Pseudechiniscus. This highlights the global distribution of Pseudechiniscus, differing from what was recently discovered for another echiniscid genus (i.e. Testechiniscus; Gąsiorek et al., 2018a). While all Pseudechiniscus specimens clustered together in a well-supported group, their relationships with other members of the recently erected subfamily Pseudechiniscinae (Guil et al., 2019) appear less evident. In fact, our analysis finds good support for the Pseudechiniscus + Proechiniscus + Cornechiniscus + Acanthechiniscus lineage, but it does exclude all Mopsechiniscus specimens from this evolutionary lineage, also negating the tentative including of this genus inside the Pseudechiniscini tribe (Guil et al., 2019). Therefore, more in-depth analyses will be needed in order to confirm or disprove this new Echiniscidae systematics.

Two species-groups were identified inside Pseudechiniscus, recognizable by both morphological and molecular approaches, i.e. the $P$. novaezealandiae group (characterized by an elongated cephalic papilla) and $P$. suillus-facettalis group (characterized a domelike cephalic papilla; Fig. 5). This datum is also confirmed by a morphological phylogenetic analysis by Gąsiorek et al. (2018c), in which $P$. novaezealandiae and $P$. suillus are two clearly separated lineages. These species groups could be described as new subgenera, but we think that more integrative data are necessary in order to erect new taxa, especially for the $P$. novaezealandiae group.

However, no clear-cut subdivision could be found between $P$. suillus and P. facettalis specimens. Even though some previous authors (Ramazzotti \& Maucci, 1983; Gąsiorek \& Degma, 2018) used the presence of faceting in the terminal plate to discriminate between these two species, this character was not detectable and, therefore, it was not possible to unambiguously identify specimens. Considering that also Dastych (1988) synonymized $P$. suillus and $P$. facettalis, the taxonomic status of these two species is not well defined and needs revision.

The integrative analysis allows us a clear-cut identification of the specimens from Slovakia. They all have a peculiar ventral sculpture, characterized by a reticulated pattern (Fig. 1E, F), similar to that exhibited by $P$. xiai, sampled in the Liupan Mountains (Central China; Wang et al., 2018). The molecular results of Slovakian specimens clearly point to a welldefined taxon (Fig. 6) but, unfortunately, no molecular data are presently available for the type population of $P$. xiai. Given the large geographical distance and the small morphological differences between Slovakian and Chinese specimens (divided median plate 2, plate IV slightly faceted in some individuals), presently there are no definitive elements to assign the Slovakian specimens to $P$. xiai or to a new species.

The present study reveals the presence of semicryptic species in the genus Pseudechiniscus (Fig. 6). At least seven different putative species are found: while for some of them there is at least a geographical subdivision (e.g. Italy and Iberian Peninsula), in other cases four and two different putative species are found in the same gathering (Mongolia C2592 and Mongolia C2595, respectively), with one putative species shared between the two sampling sites. The presence of cryptic species in tardigrades has been known since Faurby et al. (2008) found high genetic distances in a single morphotype of Ramazzottius oberhaeuseri (Doyère, 1840). Even though some criticisms have recently arisen about the cryptic status of these molecularly identified species (Stec et al., 2018a), the fact that taxonomically important morphological characters are scarce in tardigrades must not be underrated. Actually, the application of an integrated approach has allowed the definition of many tardigrade species (Cesari et al., 2009, 2011; 2016b; Bertolani et al., 2011a, b; Guidetti et al., 2013, 2014; Vicente et al., 2013; Stec et al., 2015, 2017a, b, c, 2018b, c, d, e; Gąsiorek et al., 2016, 2017a, b, c, 2018b; Møbjerg et al., 2016; Morek et al., 2016; Zawierucha et al., 2016, 2018; Roszkowska et al. 2017, 2018; Buda et al., 2018; Kaczmarek et al., 2018; Nowak \& Stec, 2018; Perry et al., 2018), but it also pointed out that many difficult taxonomic situations still exist in both Heterotardigrada and Eutardigrada, and it evidenced the surprisingly large presence of putative cryptic species in the phylum (Guidetti et al., 2009, 2016, 2019; Guil \& Giribet,

Figure 2. Pseudechiniscus specimens from Portugal (C3039), light microscopy (LM, phase contrast) and scanning electron microscopy (SEM). A, head with cephalic papilla (arrow, LM). B, head with cephalic papilla (arrow, SEM). C, terminal (caudal) plate (IV) (LM). D, terminal (caudal) plate (IV; SEM). E, ventral sculpture and male gonopore (arrow; LM). F, detail of the ventral sculpture and male gonopore (arrow, SEM). Pores in B, D, E are artefacts due to sample preparation. Scale bars: $10 \mu \mathrm{m}(\mathrm{A}, \mathrm{B}, \mathrm{C}, \mathrm{E}, \mathrm{F}) ; 20 \mu \mathrm{m}(\mathrm{D})$. 

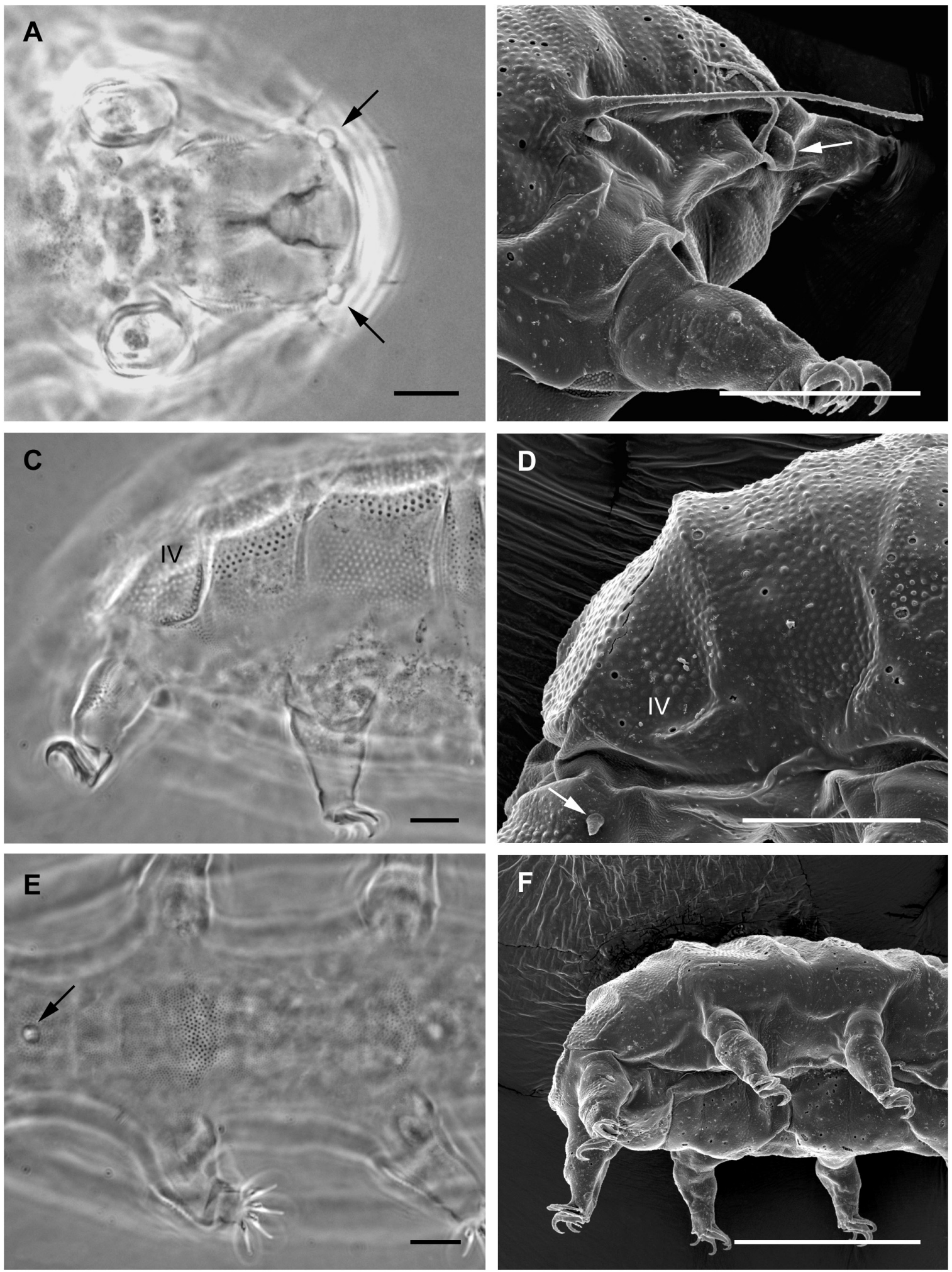

Figure 3. Pseudechiniscus specimens from Italy (C3842), light microscopy (LM, phase contrast) and scanning electron microscopy (SEM). A, cephalic papillae (arrows, LM). B, head with cephalic papilla (arrow, SEM). C, terminal (caudal) plate (IV, LM). D, terminal (caudal) plate (IV) and papilla (arrow) on the fourth pair of legs; SEM). E, ventral sculpture and male gonopore (arrow; LM). F, ventral sculpture (SEM). Pores in B, D, F are artefacts due to sample preparation. Scale bars: $10 \mu \mathrm{m}(\mathrm{A}, \mathrm{C}, \mathrm{E}) ; 20 \mu \mathrm{m}(\mathrm{B}, \mathrm{D}) ; 40 \mu \mathrm{m}(\mathrm{F})$. 

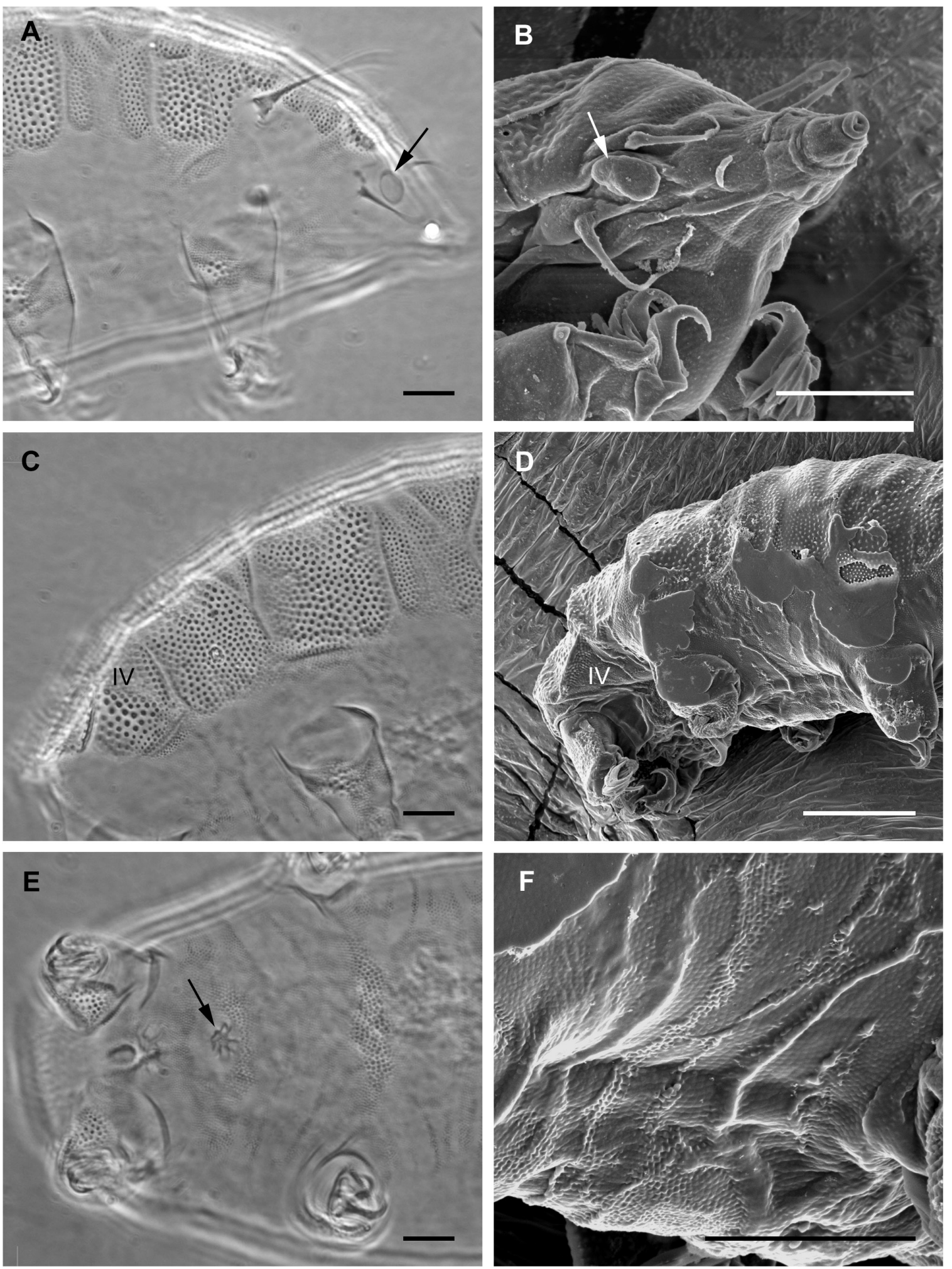

Figure 4. Pseudechiniscus specimens from Mongolia (C2592 and C2595), light microscopy (LM, phase contrast) and scanning electron microscopy (SEM). A, cephalic papilla (arrow, LM). B, head with cephalic papilla (arrow, SEM). C, terminal (caudal) plate (IV, LM). D, terminal (caudal) plate (IV, SEM). E, ventral sculpture and female gonopore (arrow; LM). F, detail of the cuticle ventral sculpture (SEM). Pores in A are artefacts due to sample preparation. Scale bars: $10 \mu \mathrm{m}$ (A, B, C, E, F); $20 \mu \mathrm{m}(\mathrm{D})$. 


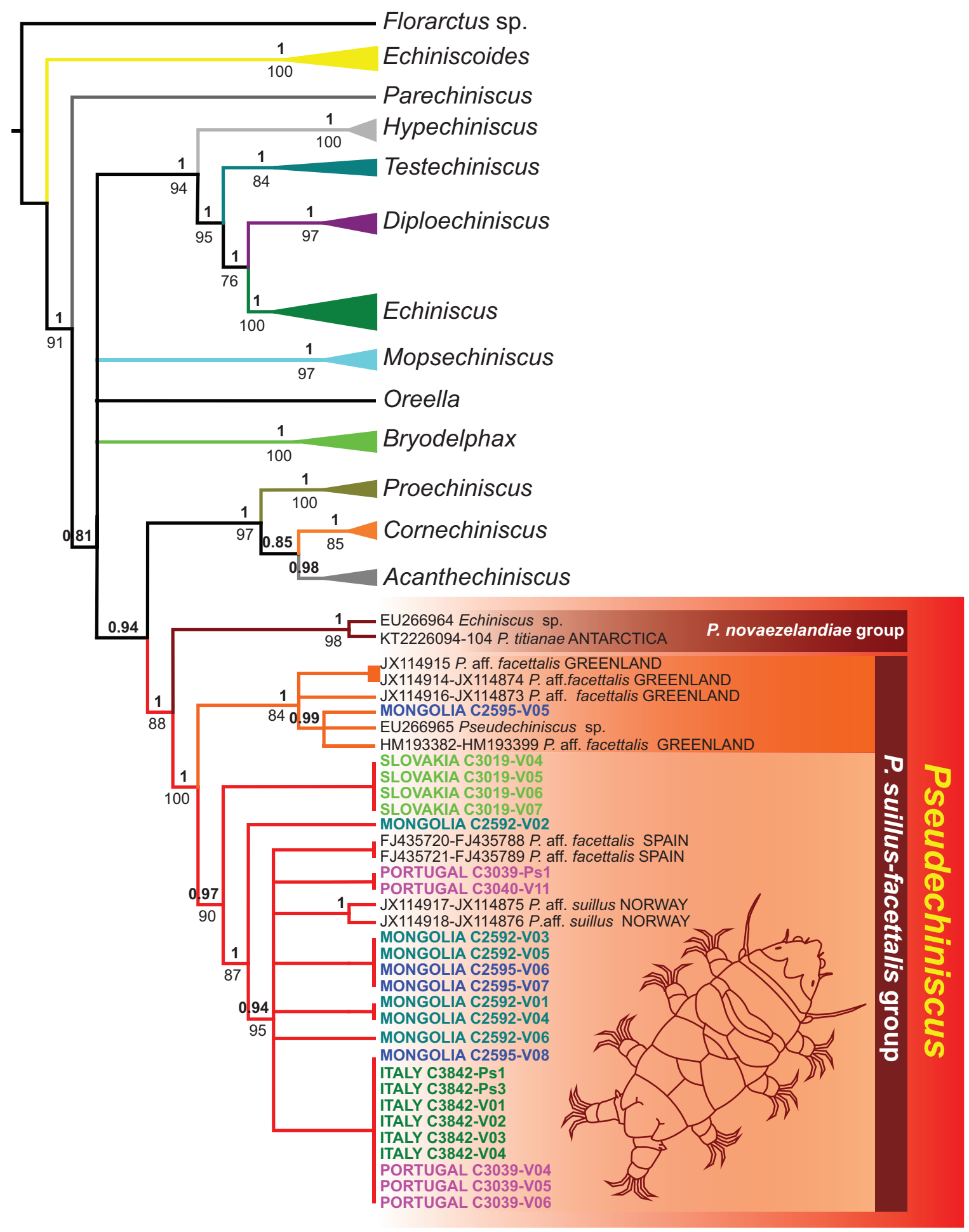

Figure 5. Phylogenetic reconstruction [Bayesian inference (BI) and maximum likelihood (ML) analyses] based on combined dataset (1652 bp of $18 \mathrm{~S}+28 \mathrm{~S}$ genes). Values in bold and above branches indicate posterior probability values (BI), while values below branches show bootstrap values (ML). Newly analysed specimens are in bold. 

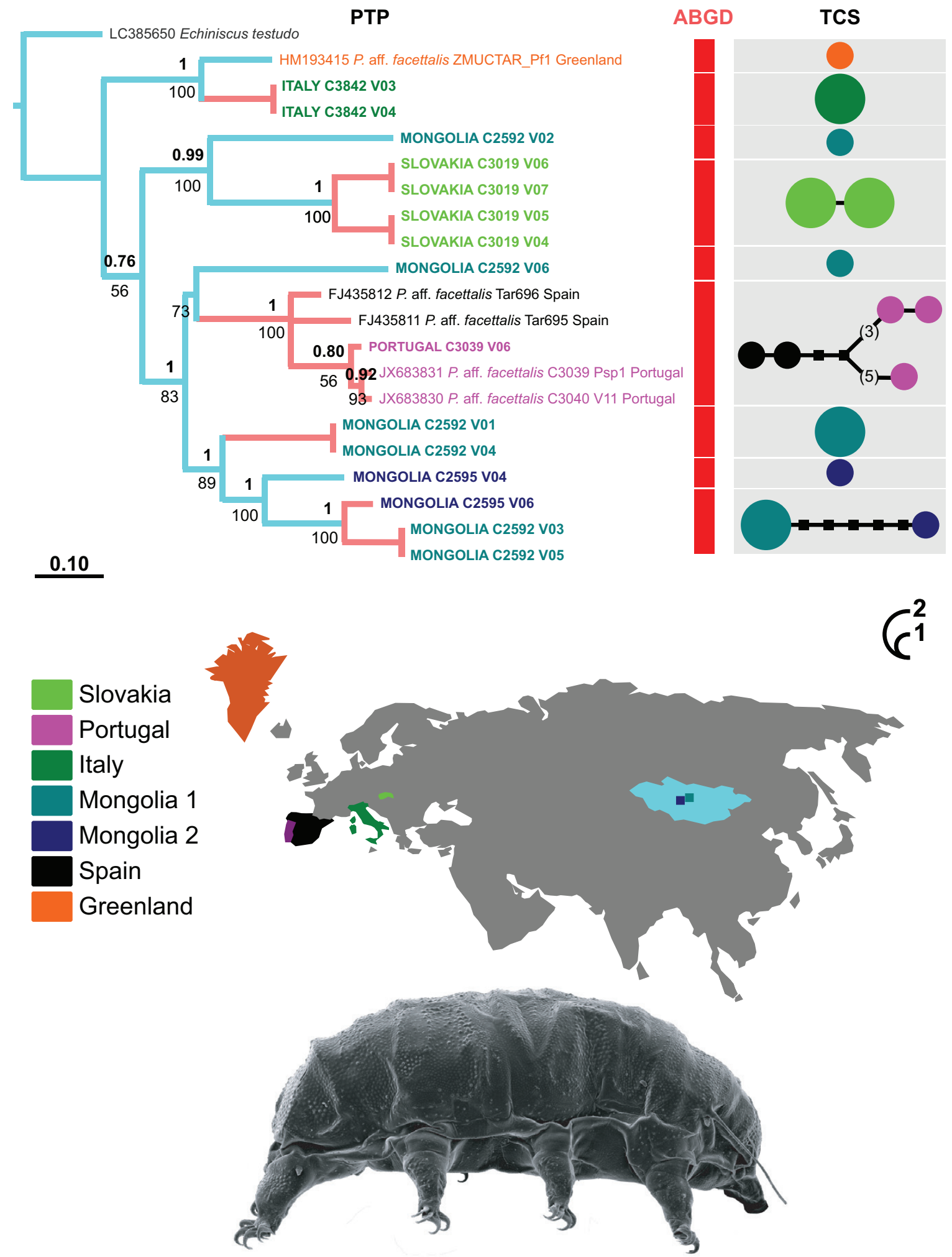

Figure 6. Left: tree resulting from the maximum likelihood (ML) and Bayesian inference (BI) analysis of 22 cytochrome $c$ oxidase subunit I newly analysed Pseudechiniscus specimens and sequences from GenBank. Values in bold above branches point out posterior probability values (BI), while values below branches show bootstrap values (ML). Results of the Poisson tree process analysis are provided using differently coloured branches: putative species are indicated using transitions from 
Table 2. List of unconfirmed candidate species (UCS) of Pseudechiniscus found in this study

\begin{tabular}{|c|c|}
\hline UCS & Specimens \\
\hline \multirow[t]{5}{*}{ Pseudechiniscus aff. facettalis [Ca1; Cesari et al., 2019] } & PORTUGAL C3039 V06 \\
\hline & JX683831 P. aff. facettalis C3039 Psp1 Portugal \\
\hline & JX683830 P. aff. facettalis C3040 V11 Portugal \\
\hline & FJ435812 P. aff. facettalis Tar696 Spain \\
\hline & FJ435811 P. aff. facettalis Tar695 Spain \\
\hline \multirow[t]{2}{*}{ Pseudechiniscus aff. suillus [Ca1; Cesari et al., 2019] } & ITALY C3842 V03 \\
\hline & ITALY C3842 V04 \\
\hline \multirow[t]{2}{*}{ Pseudechiniscus aff. suillus [Ca2; Cesari et al., 2019] } & MONGOLIA C2592 V01 \\
\hline & MONGOLIA C2592 V04 \\
\hline \multirow[t]{3}{*}{ Pseudechiniscus aff. suillus [Ca3; Cesari et al., 2019] } & MONGOLIA C2595 V06 \\
\hline & MONGOLIA C2592 V03 \\
\hline & MONGOLIA C2592 V05 \\
\hline Pseudechiniscus aff. suillus [Ca4; Cesari et al., 2019] & MONGOLIA C2595 V04 \\
\hline Pseudechiniscus aff. suillus [Ca5; Cesari et al., 2019] & MONGOLIA C2592 V02 \\
\hline Pseudechiniscus aff. suillus [Ca6; Cesari et al., 2019] & MONGOLIA C2592 V06 \\
\hline \multirow[t]{4}{*}{ Pseudechiniscus aff. xiai [Ca1; Cesari et al., 2019] } & SLOVAKIA C3019 V04 \\
\hline & SLOVAKIA C3019 V05 \\
\hline & SLOVAKIA C3019 V06 \\
\hline & SLOVAKIA C3019 V07 \\
\hline
\end{tabular}

2009; Bertolani et al., 2011b; Faurby et al., 2011, 2012; Faurby \& Barber, 2015; Cesari et al., 2016a; Stec et al., 2018a; Morek et al., 2019). Presently, the most sensible solution would be to place species difficult to distinguish into the category of cryptic or semicryptic species (complexes that may display minor, but still detectable, morphological differences; Korshunova et al., 2017) until new diagnosable characters are found (Bickford et al., 2007). Evolutionary lineages identified only by molecular methods should not be described as new species, but temporarily be considered unidentified candidate species (UCS; Padial et al., 2010). This will allow the flagging of potentially delicate situations and the call for the use of different approaches (e.g. karyological, ecological, ethological, etc.) and possible new genetic markers. The present taxonomic situation in the $P$. suillus-facettalis group appears intricate due to several factors: (1) the original description of $P$. suillus is dated and incomplete, (2) the discrimination between $P$. suillus and $P$. facettalis is problematic and (3) recent morphological (e.g. ventral cuticular pattern) and morphometric characters are still not applied to a large number of taxa in order to be reliable for a clear intra- and interspecific discrimination. Therefore, considering the low morphological variability and the lack of morphometric data in our studied populations, we designate eight Pseudechiniscus (semi)cryptic species as UCS. Following Padial et al. (2010), these UCS should be defined with the combination of the binomial name of the most similar species, followed (in square brackets) by the abbreviation ' $\mathrm{Ca}$ ' (for candidate) with an attached numerical code referring to the particular candidate species and terminating with the author name and year of publication of the article (i.e. this paper) in which the lineage was first discovered. In order to be more precise, we also have decided to designate these lineages as part of a species group by adding the affinis designation (aff.). One UCS (Portuguese specimens) is designed as $P$. aff. facettalis because the obtained sequences match with four GenBank sequences assigned to $P$. facettalis (FJ435811-2; JX683830-1). Another UCS (Slovak specimens) is attributed to $P$. aff. xiai because it is the most similar described species, even though some small morphological differences are

blue-coloured branches to red-coloured branches. Newly scored haplotypes are in bold. The scale bar shows the number of substitutions per nucleotide position. Centre: orange rectangles represent specimens grouped by ABGD analysis. Right: haplotype network of COI gene in Pseudechiniscus. Circles represent haplotypes, while circle surface denotes haplotype frequency. Small black squares indicate missing/ideal haplotypes. Networks falling below the value of the $95 \%$ connection limit are disconnected. Grey rectangles delimitate putative species. 
present (see above). Finally, all other UCS are designed as $P$. aff. suillus, as they are not distinguishable from the original description of this taxon. Table 2 lists all the UCS found in this study.

The integrated approach to the study of Pseudechiniscus allows confirmation of its monophyly and highlights the relationships in the taxon. The present study also, for the first time, reports the presence of semicryptic species in the P. suillus-facettalis group, and underlines the taxonomic problems related to this group. New studies will be performed in the future to further highlight the taxonomic relationships and the biodiversity of this peculiar tardigrade taxon.

\section{ACKNOWLEDGEMENTS}

This work was supported by the grant from the European Commission (FPVII) Integrated Infrastructure Initiative program SYNTHESYS (ref. no. DK-TAF-4619) to MC. We thank Arctic Station, Qeqertarsuaq, Greenland for permit to collect Pseudechiniscus and other genera of heterotardigrades in the protected area of the Arctic Station.

\section{REFERENCES}

Bertolani R, Biserov VI, Rebecchi L, Cesari M. 2011a. Taxonomy and biogeography of tardigrades using an integrated approach: new results on species of the Macrobiotus hufelandi group. Invertebrate Zoology 8: 23-36.

Bertolani R, Rebecchi L, Giovannini I, Cesari M. 2011 b. DNA barcoding and integrative taxonomy of Macrobiotus hufelandi C. A. S. Schultze 1834, the first tardigrade species to be described, and some related species. Zootaxa 2997: $19-36$.

Bickford D, Lohman DJ, Sodhi NS, Ng PK, Meier R, Winker K, Ingram KK, Das I. 2007. Cryptic species as a window on diversity and conservation. Trends in Ecology and Evolution 22: 148-155.

Buda J, Olszanowski Z, Wierzgoń M, Zawierucha $\mathbf{K}$. 2018. Tardigrades and oribatid mites in bryophytes from geothermally active lava fields (Krafla, Iceland) and the description of Pilatobius islandicus sp. nov. (Eutardigrada). Polish Polar Research 39: 425-453.

Cesari M, Bertolani R, Rebecchi L, Guidetti R. 2009. DNA barcoding in Tardigrada: the first case study on Macrobiotus macrocalix Bertolani \& Rebecchi 1993 (Eutardigrada, Macrobiotidae). Molecular Ecology Resources 9: 699-706.

Cesari M, Giovannini I, Bertolani R, Rebecchi L. 2011. An example of problems associated with DNA barcoding in tardigrades: a novel method for obtaining voucher specimens. Zootaxa 3104: 42-51.

Cesari M, McInnes SJ, Bertolani R, Rebecchi L, Guidetti R. 2016a. Genetic diversity and biogeography of the south polar water bear Acutuncus antarcticus
(Eutardigrada: Hypsibiidae) - evidence that it is a truly panAntarctic species. Invertebrate Systematics 30: 635-649.

Cesari M, Vecchi M, Palmer A, Bertolani R, Pilato G, Rebecchi L, Guidetti R. 2016b. What if the claws are reduced? Morphological and molecular phylogenetic relationships of the genus Haplomacrobiotus May, 1948 (Eutardigrada, Parachela).Zoological Journal of the Linnean Society 178: 819-827.

Clement M, Posada D, Crandall K. 2000. TCS: a computer program to estimate gene genealogies. Molecular Ecology 9: 1657-1660.

Darriba D, Taboada GL, Doallo R, Posada D. 2012. jModelTest 2: more models, new heuristics and parallel computing. Nature Methods 9: 772.

Dastych H. 1984. The tardigrada from Antarctic with descriptions of several new species. Acta Zoologica Cracoviensia 27: 377-436.

Dastych H. 1988. The Tardigrada of Poland. Monografie Fauny Polski 16: 1-255.

Degma P, Guidetti R. 2007. Notes to the current checklist of Tardigrada. Zootaxa 1579: 41-53.

Degma P, Bertolani R, Guidetti R. 2018. Actual checklist of Tardigrada species. 48. Available at: http://www.tardigrada. modena.unimo.it/miscellanea/Actual $\% 20$ checklist $\% 20$ of $\% 20$ Tardigrada.pdf (accessed 6 June 2019).

Faurby S, Barber PH. 2015. Extreme population subdivision despite high colonization ability: contrasting regional patterns in intertidal tardigrades from the west coast of North America. Journal of Biogeography 42: 1006-1017.

Faurby S, Jönsson KI, Rebecchi L, Funch P. 2008. Variation in anhydrobiotic survival of two eutardigrade morphospecies: a story of cryptic species and their dispersal. Journal of Zoology 275: 139-145.

Faurby S, Jørgensen A, Kristensen RM, Funch P. 2011. Phylogeography of North Atlantic intertidal tardigrades: refugia, cryptic speciation and the history of the Mid-Atlantic Islands. Journal of Biogeography 38: 1613-1624.

Faurby S, Jørgensen A, Kristensen RM, Funch P. 2012. Distribution and speciation in marine intertidal tardigrades: testing the roles of climatic and geographical isolation. Journal of Biogeography 39: 1596-1607.

Fontoura P, Morais P. 2011. Assessment of traditional and geometric morphometrics for discriminating cryptic species of the Pseudechiniscus suillus complex (Tardigrada, Echiniscidae). Journal of Zoological Systematics and Evolutionary Research 49: 26-33.

Gąsiorek P, Degma P. 2018. Three Echiniscidae species (Tardigrada: Heterotardigrada) new to the Polish fauna, with the description of a new gonochoristic Bryodelphax Thulin, 1928. Zootaxa 4410: 77-96.

Gąsiorek P, Stec D, Morek W, Zawierucha K, Kaczmarek $\mathbf{L}$, Lachowska-Cierlik D, Michalczyk $\mathbf{\iota}$. 2016. An integrative revision of Mesocrista Pilato, 1987 (Tardigrada: Eutardigrada: Hypsibiidae). Journal of Natural History 50: 2803-2828.

Gąsiorek P, Stec D, Morek W, Michalczyk Ł. 2017a. An integrative redescription of Echiniscus testudo (Doyère, 1840), the nominal taxon for the class Heterotardigrada 
(Ecdysozoa: Panarthropoda: Tardigrada). Zoologischer Anzeiger 270: 107-122.

Gąsiorek P, Stec D, Morek W, Marnissi J, Michalczyk E. 2017b. The tardigrade fauna of Tunisia, with an integrative description of Bryodelphax maculatus sp. nov. (Heterotardigrada: Echiniscidae). African Zoology 52: 77-89.

Gąsiorek P, Zawierucha K, Stec D, Michalczyk Ł. 2017c. Integrative redescription of a common Arctic water bear Pilatobius recamieri (Richters, 1911). Polar Biology 40: 2239-2252.

Gąsiorek P, Stec D, Zawierucha K, Kristensen RM, Michalczyk Ł. 2018a. Revision of Testechiniscus Kristensen, 1987 (Heterotardigrada: Echiniscidae) refutes the polartemperate distribution of the genus. Zootaxa 4472: 261-297.

Gąsiorek P, Stec D, Morek W, Michalczyk L. 2018b. An integrative redescription of Hypsibius dujardini (Doyère, 1840), the nominal taxon for Hypsibioidea (Tardigrada: Eutardigrada). Zootaxa 4415: 45-75.

Gąsiorek P, Suzuki A, Kristensen RM, LachowskaCierlik D, Michalczyk Ł. 2018c. Untangling the Echiniscus Gordian knot: Stellariscus gen. nov. (Heterotardigrada: Echiniscidae) from Far East Asia. Invertebrate Systematics 32: 1234-1247.

Grothman GT, Johanson C, Chilton G, Kagoshima H, Tsujimoto M, Suzuki AC. 2017. Gilbert Rahm and the status of Mesotardigrada Rahm, 1937. Zoological Sciences 34: $5-10$.

Guidetti R, Bertolani R. 2005. Tardigrade taxonomy: an updated check list of the taxa and a list of characters for their identification. Zootaxa 845: 1-46.

Guidetti R, Schill RO, Bertolani R, Dandekar T, Wolf M. 2009. New molecular data for tardigrade phylogeny, with the erection of Paramacrobiotus gen. nov. Journal of Zoological Systematics and Evolutionary Research 47: 315-321.

Guidetti R, Peluffo JR, Rocha AM, Cesari M, Moly de Peluffo MC. 2013. The morphological and molecular analyses of a new South American urban tardigrade offer new insights on the biological meaning of the Macrobiotus hufelandi group of species (Tardigrada: Macrobiotidae). Journal of Natural History 47: 2409-2426.

Guidetti R. Rebecchi L, Cesari M, McInnes SJ. 2014. Mopsechiniscus franciscae, a new species of a rare genus of Tardigrada from continental Antarctica. Polar Biology 37: 1221-1233.

Guidetti R, Rebecchi L, Bertolani R, Jönsson KI, Kristensen RM, Cesari M. 2016. Morphological and molecular analyses on Richtersius (Eutardigrada) diversity reveal its new systematic position and lead to the establishment of a new genus and a new family within Macrobiotoidea. Zoological Journal of the Linnean Society 178: 834-845.

Guidetti R, Cesari M, Bertolani R, Altiero T, Rebecchi L. 2019. High diversity in species, reproductive modes and distribution within the Paramacrobiotus richtersi complex (Eutardigrada, Macrobiotidae). Zoological Letters 5: 1.

Guil N, Giribet G. 2009. Fine scale population structure in the Echiniscus blumi-canadensis series (Heterotardigrada, Tardigrada) in an Iberian mountain range. When morphology fails to explain genetic structure. Molecular Phylogenetics and Evolution 51: 606-613.

Guil N, Giribet G. 2012. A comprehensive molecular phylogeny of tardigrades - adding genes and taxa to a poorly resolved phylum-level phylogeny. Cladistics 28: 21-49.

Guil N, Jørgensen A, Giribet G, Kristensen RM. 2013. Congruence between molecular phylogeny and cuticular design in Echiniscoidea (Tardigrada, Heterotardigrada). Zoological Journal of the Linnean Society 169: 713-736.

Guil N, Jørgensen A, Kristensen RM. 2019. An upgraded comprehensive multilocus phylogeny of the Tardigrada tree of life. Zoological Scripta 48: 120-137.

Guindon S, Gascuel O. 2003. A simple, fast and accurate method to estimate large phylogenies by maximumlikelihood. Systematic Biology 52: 696-704.

Hart MW, Sunday J. 2007. Things fall apart: biological species form unconnected parsimony networks. Biology Letters 3: 509-512.

Huelsenbeck JP, Ronquist F. 2001. MRBAYES: Bayesian inference of phylogeny. Bioinformatics 17: 754-755.

Jørgensen A, Faurby S, Hansen JG, Møbjerg N, Kristensen RM. 2010. Molecular phylogeny of Arthrotardigrada (Tardigrada). Molecular Phylogenetics and Evolution 54: 1006-1015.

Jørgensen A, Møbjerg N, Kristensen RM. 2011. Phylogeny and evolution of the Echiniscidae (Echiniscoidea, Tardigrada) - an investigation of the congruence between molecules and morphology. Journal of Zoological Systematics and Evolutionary Research 49: 6-16.

Kaczmarek Ł, Zawierucha K, Buda J, Stec D, Gawlak M, Michalczyk $\mathbf{L}$, Roszkowska M. 2018. An integrative redescription of the nominal taxon for the Mesobiotus harmsworthi group (Tardigrada: Macrobiotidae) leads to descriptions of two new Mesobiotus species from Arctic. PLoS One 13: e0204756.

Kathman RD, Dastych H. 1990. Some Echiniscidae (Tardigrada: Heterotardigrada) from Vancouver Island, British Columbia, Canada. Canadian Journal of Zoology 68: 699-706.

Katoh K, Misawa K, Kuma KI, Miyata T. 2002. MAFFT: a novel method for rapid multiple sequence alignment based on fast Fourier transform. Nucleic Acids Research 30: 3059-3066.

Katoh K, Rozewicki J, Yamada KD. 2017. MAFFT online service: multiple sequence alignment, interactive sequence choice and visualization. Briefings in Bioinformatics: 1-7. doi:10.1093/bib/bbx108

Korshunova T, Martynov A, Bakken T, Picton B. 2017. External diversity is restrained by internal conservatism: new nudibranch mollusc contributes to the cryptic species problem. Zoologica Scripta 46: 683-692.

Kristensen RM. 1987. Generic revision of the Echiniscidae (Heterotardigrada), with a discussion of the origin of the family. In: Bertolani R, ed. Biology of tardigrades. Selected symposia and monographs. U.Z.I., Vol. 1. Modena: Mucchi, 261-335.

Kumar S, Stecher G, Tamura K. 2016. MEGA7: molecular evolutionary genetics analysis version 7.0 for bigger datasets. Molecular Biology and Evolution 33: 1870-1874. 
Marcus E. 1929. Tardigrada. In: Bronn HG, ed. Klassen und Ordnungen des Tierreichs. Sec. 4, Part 3, Vol. 5. Leipzig: Akademische Verlagsgesellschaft, 1-608.

Maucci W. 1973-74. Tardigradi muscicoli del Carso Triestino. Bollettino della Società Adriatica di Scienze di Trieste 59: 107-150.

Miller MA, Pfeiffer W, Schwartz T. 2010. Creating the CIPRES science gateway for inference of large phylogenetic trees. In: Proceedings of the Gateway Computing Environments Workshop (GCE), 14 November 2010, New Orleans, 1-8.

Møbjerg N, Kristensen RM, Jørgensen A. 2016. Data from new taxa infer Isoechiniscoides gen. nov. and increase the phylogenetic and evolutionary understanding of echiniscoidid tardigrades (Echiniscoidea: Tardigrada). Zoological Journal of the Linnean Society 178: 804-818.

Morek W, Gąsiorek P, Stec D, Blagden B, Michalczyk Ł. 2016. Experimental taxonomy exposes ontogenetic variability and elucidates the taxonomic value of claw configuration in Milnesium Doyère, 1840 (Tardigrada: Eutardigrada: Apochela). Contributions to Zoology 85: 173-200.

Morek W, Stec D, Gąsiorek P, Surmacz B, Michalczyk Ł. 2019. Milnesium tardigradum Doyère, 1840: The first integrative study of interpopulation variability in a tardigrade species. Journal of Zoological Systematics and Evolutionary Research 57: 1-23.

Nowak B, Stec D. 2018. An integrative description of Macrobiotus hannae sp. nov. (Tardigrada: Eutardigrada: Macrobiotidae: hufelandi group) from Poland. Turkish Journal of Zoology 42: 269-286.

Padial JM, Miralles A, De la Riva I, Vences M. 2010. The integrative future of taxonomy. Frontiers in Zoology 7: 16.

Perry ES, Rawson P, Ameral NJ, Miller WR, Miller JD. 2018. Echiniscoides rugostellatus a new marine tardigrade from Washington, USA (Heterotardigrada: Echiniscoidea: Echiniscoididae: Echiniscoidinae). Proceedings of the Biological Society of Washington 131: 182-193.

Petersen B. 1951. The tardigrade fauna of Greenland. Meddelelser om Grønland 150: 1-94.

Puillandre N, Lambert A, Brouillet S, Achaz G. 2012. ABGD, Automatic Barcode Gap Discovery for primary species delimitation. Molecular Ecology 21: 1864-1877.

Rahm G. 1937. A new ordo of tardigrades from the hot springs of Japan (Furu-yu section, Unzen). Annotationes Zoologicae Japonensis 16: 345-353.

Ramazzotti G, Maucci W. 1983. Il Phylum Tardigrada. Terza edizione riveduta e corretta. Memorie dell'Istituto Italiano di Idrobiologia 41: 1-1012.

Rambaut A, Drummond AJ. 2007. Tracer v1.5. Available at: http://beast.bio.ed.ac.uk (accessed 6 June 2019).

Ronquist F, Huelsenbeck JP. 2003. MRBAYES 3: Bayesian phylogenetic inference under mixed models. Bioinformatics 19: $1572-1574$.

Roszkowska M, Ostrowska M, Stec D, Janko K, Kaczmarek Ł. 2017. Macrobiotus polypiformis sp. nov., a new tardigrade (Macrobiotidae; hufelandi group) from the Ecuadorian Pacific coast, with remarks on the claw abnormalities in eutardigrades. European Journal of Taxonomy 327: 1-19.

Roszkowska M, Stec D, Gawlak M, Kaczmarek Ł. 2018. An integrative description of a new tardigrade species Mesobiotus romani sp. nov. (Macrobiotidae: harmsworthi group) from the Ecuadorian Pacific coast. Zootaxa 4450: 550-564.

Santos AM, Cabezas MP, Tavares AI, Xavier R, Branco M. 2015. tcsBU: a tool to extend TCS network layout and visualization. Bioinformatics 32: 627-628.

Stamatakis A, Hoover P, Rougemont J. 2008. A rapid bootstrap algorithm for the RAxML web servers. Systematic Biology 57: 758-771.

Stamatakis A. 2006. RAxML-VI-HPC: maximum likelihoodbased phylogenetic analyses with thousands of taxa and mixed models. Bioinformatics 22: 2688-2690.

Stec D, Smolak R, Kaczmarek Ł, Michalczyk Ł. 2015. An integrative description of Macrobiotus paulinae sp. nov. (Tardigrada: Eutardigrada: Macrobiotidae: hufelandi group) from Kenya. Zootaxa 4052: 501-526.

Stec D, Zawierucha K, Michalczyk $€$, 2017a. An integrative description of Ramazzottius subanomalus - (Tardigrada) from Poland. Zootaxa 4300: 403-420.

Stec D, Morek W, Gąsiorek P, Blagden B, Michalczyk $\mathbf{~}$. 2017b. Description of Macrobiotus scoticus sp. nov. (Tardigrada: Macrobiotidae: hufelandi Group) from Scotland by means of integrative taxonomy. Annales Zoologici 67: 181-197.

Stec D, Roszkowska M, Kaczmarek Ł, Michalczyk Ł. 2017c. Paramacrobiotus lachowskae, a new species of Tardigrada from Colombia (Eutardigrada: Parachela: Macrobiotidae). New Zealand Journal of Zoology 45: 43-60.

Stec D, Morek W, Gąsiorek P, Michalczyk Ł. 2018a. Unmasking hidden species diversity within the Ramazzottius oberhaeuseri complex, with an integrative redescription of the nominal species for the family Ramazzottiidae (Tardigrada: Eutardigrada: Parachela). Systematics and Biodiversity 16: 357-376.

Stec D, Arakawa K, Michalczyk Ł. 2018b. An integrative description of Macrobiotus shonaicus sp. nov. (Tardigrada: Macrobiotidae) from Japan with notes on its phylogenetic position within the hufelandi group. PLoS One 13: e0192210.

Stec D, Krzywański Ł, Michalczyk Ł. 2018c. Integrative description of Macrobiotus canaricus sp. nov. with notes on $M$. recens (Eutardigrada: Macrobiotidae). European Journal of Taxonomy 452: 1-36.

Stec D, Kristensen RM, Michalczyk Ł. 2018d. Integrative taxonomy identifies Macrobiotus papei, a new tardigrade species of the Macrobiotus hufelandi complex (Eutardigrada: Macrobiotidae) from the Udzungwa Mountains National Park (Tanzania). Zootaxa 4446: 273-291.

Stec D, Roszkowska M, Kaczmarek $\mathbf{E}$, Michalczyk $\mathbf{~}$. 2018e. An integrative description of a population of Mesobiotus radiatus (Pilato, Binda \& Catanzaro, 1991) from Kenya. Turkish Journal of Zoology 42: 523-540.

Tang CQ, Humphreys AM, Fontaneto D, Barraclough TG. 2014. Effects of phylogenetic reconstruction method of the robustness of species delimitation using single-locus data. Methods in Ecology and Evolution 5: 1086-1094. 
Templeton AR, Crandall KA, Sing CF. 1992. A cladistic analysis of phenotypic associations with haplotypes inferred from restriction endonuclease mapping and DNA sequence data. III. Cladogram estimation. Genetics 132: 619-633.

Vecchi M, Cesari M, Bertolani R, Jönsson KI, Rebecchi L, Guidetti R. 2016. Integrative systematic studies on tardigrades from Antarctica identify new genera and new species within Macrobiotoidea and Echiniscoidea. Invertebrate Systematics 30: 303-322.

Vicente F, Fontoura P, Cesari M, Rebecchi L, Guidetti R, Serrano A, Bertolani R. 2013. Integrative taxonomy allows the identification of synonymous species and the erection of a new genus of Echiniscidae (Tardigrada, Heterotardigrada). Zootaxa 3613: 557-572.
Wang L, Xue J, Xiaochen L. 2018. A description of Pseudechiniscus xiai sp. nov., with a key to genus Pseudechiniscus in China. Zootaxa 4388: 255-264.

Zawierucha K, Kolicka M, Kaczmarek L. 2016. Re-description of the Arctic tardigrade Tenuibiotus voronkovi (Tumanov, 2007) (Eutardigrada; Macrobiotidea), with the first molecular data for the genus. Zootaxa 4196: 498-510.

Zawierucha K, Stec D, Lachowska-Cierlik D, Takeuchi N, Li Z, Michalczyk Ł. 2018. High mitochondrial diversity in a new water bear species (Tardigrada: Eutardigrada) from mountain glaciers in Central Asia, with the erection of a new genus Cryoconicus. Annales Zoologici 68: 179-201.

Zhang J, Kapli P, Pavlidis P, Stamatakis A. 2013. A general species delimitation method with applications to phylogenetic placements. Bioinformatics 29: 2869-2876.

\section{SUPPORTING INFORMATION}

Additional Supporting Information may be found in the online version of this article at the publisher's web-site.

Table S1. GenBank accession numbers for the newly analysed Pseudechiniscus specimens. na: not available.

Table S2. List of the 18S, 28S and COI sequences from GenBank used for comparison.

Table S3. Uncorrected p-distance computed among all Echinischidae specimens. 